\title{
First record of the Pacific bluefin tuna Thunnus orientalis $($ Temminck \& Schlegel, 1844) from the coast off Sur, Sultanate of Oman
}

\author{
Shama Zaki, Juma Al-Mamary, Abdul Aziz Al-Marzouqi, Lubna Al-Kharusi \\ Marine Science and Fisheries Centre, Ministry of Agriculture and Fisheries, Muscat, Sultanate of Oman
}

\begin{abstract}
A single specimen of the Pacific bluefin tuna Thunnus orientalis was caught on 11 May 2017 in a longline operated about 40 nautical miles off the coast of Sur atconfluent of Sea of Oman and Arabian Sea coast of Oman. This first record of its occurrence indicates the extension of distributional range of the species to the Arabian Sea coast of Oman.
\end{abstract}

Keywords-coast off Sur, Pacific Bluefin, Arabian Sea.

\section{INTRODUCTION}

Oman has a very long coastline of $3165 \mathrm{~km}$ with connections to three seas namely the Arabian Gulf, the Gulf of Oman and the Arabian Sea. The country has rich fish biodiversity (Al-Jufaily et al., 2010). The biodiversity of fish fauna of Omani coasts had been reported by several earlier workers (Boulenger, 1887; Steindachner, 1902; Regan, 1905; Norman, 1939; White \& Barwani, 1971; Randall, 1995; Al-Abdessalaam, 1995; Fouda et al., 1997). In addition, there is scope for inclusion of several new species and new records to the list of known species of Omani fishes (McKoy et al., 2009; Jawad \& Al-Mamry, 2009). As the result, a number of new records of fish species were reported from the Sea of Oman and Arabian Sea off Oman from recent studies (Jawad \& Al-Mamry, 2009; Jayabalan et al., 2010; Al-Jufaily et al., 2010; Jawad et al. 2014).

Fishes of the genus Thunnus(Perciformes: Scombridae) are represented by eight species namely albacore, $T$. alalunga (Bonnaterre, 1788), southern bluefin tuna, $T$. maccoyii (Castelnau, 1872), bigeye tuna, T. obesus (Lowe, 1839), Pacific bluefin tuna, $T$. orientalis (Temminck \& Schlegel, 1844), Atlantic bluefin tuna, $T$. thynnus (Linnaeus, 1758), yellowfin tuna, $T$. albacares (Bonnaterre, 1788), blackfin tuna, $T$. atlanticus (Lesson, 1831) and longtail tuna, $T$. tonggol (Bleeker, 1851) from world oceans (Froese \& Pauly, 2009. Godsil, \& Byers, 1945;Collette \& Nauen 1983). Of these, Pacific bluefin tuna, T. orientalis is a commercially valuable species and is widely distributed in the Pacific Ocean(Froese \& Pauly, 2009)and seasonally inhabiting subarctic, temperate, and tropical waters in the North Pacific Ocean as well as temperate waters in the Southern Hemisphere around Australia and New Zealand (Collette et al., 2014).

Pacific bluefin tuna grows to a maximum weight of $\sim 650$ $\mathrm{kg}$, a total length of $\sim 300 \mathrm{~cm}$ and age of at least 20 years and it is the second largest species of tuna, after the Atlantic bluefin tuna (Thunnus thynnus) (Collette and Nauen, 1983; Kitagawa et al.,2007; Collette et al., 2014).Pacific blue fin tuna is highly prized in the Japanese sashimi markets and during 2014 about 17,076 t of fish were landed; however, $T$. orientalis is reported as 'Vulnerable' under IUCN red list of species (Collette et al., 2014).

(Collette and Nauen, 1983; Foreman and Ishizuk a, 1990; Bayliff, 1994) 


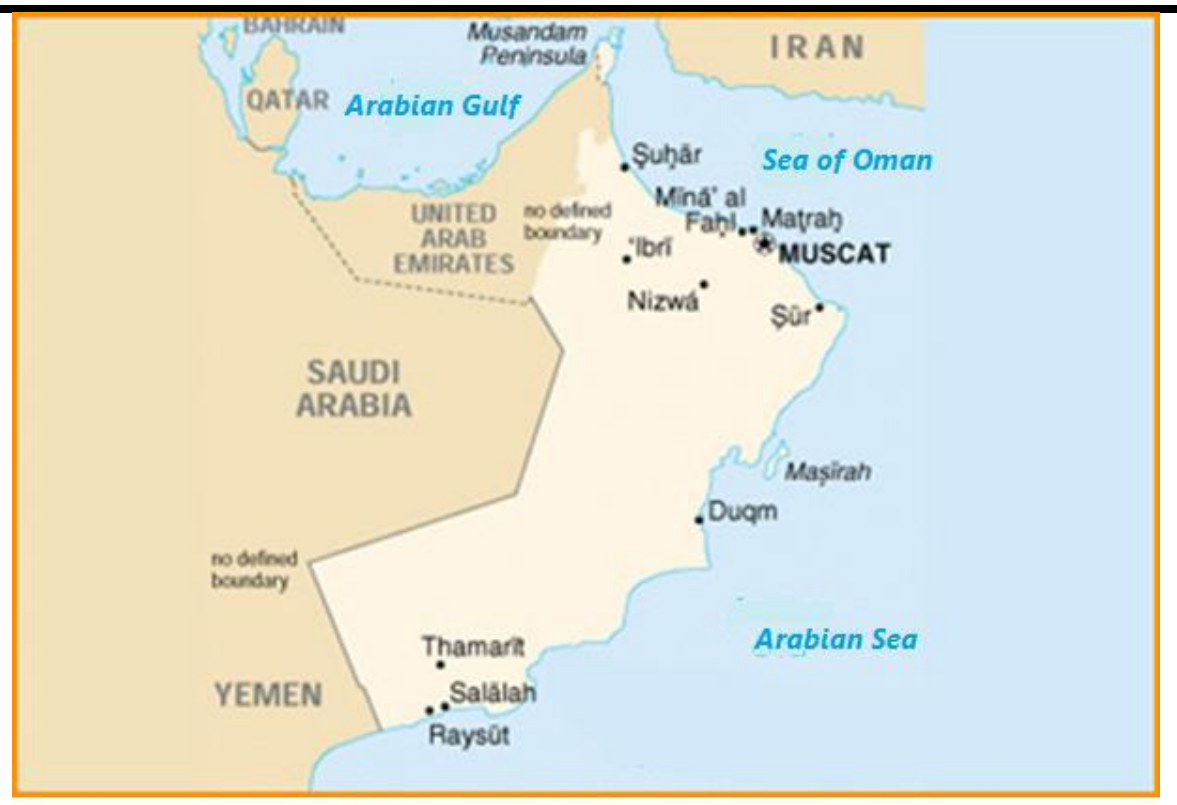

Fig.1: Map of Sultanate of Oman

From the Omani waters so far only three species such as T. tonggol, T. albacares and T. obesus are known (Godsil \& Byers, 1945; Collette et al., 2001; Randall, 1995; Froese \& Pauly, 2011).In the present report, the occurrence of single specimen of Pacific Bluefin tuna T. orientalis off the coast of Suratconfluent of Sea of Omanand Arabian Sea coast of Oman(Fig.1) is recorded for the first time.

SYSTEMATICS

Order: PERCIFORMES

Family: SCOMBRIDAE

Genus: Thunnus

Species:orientalis

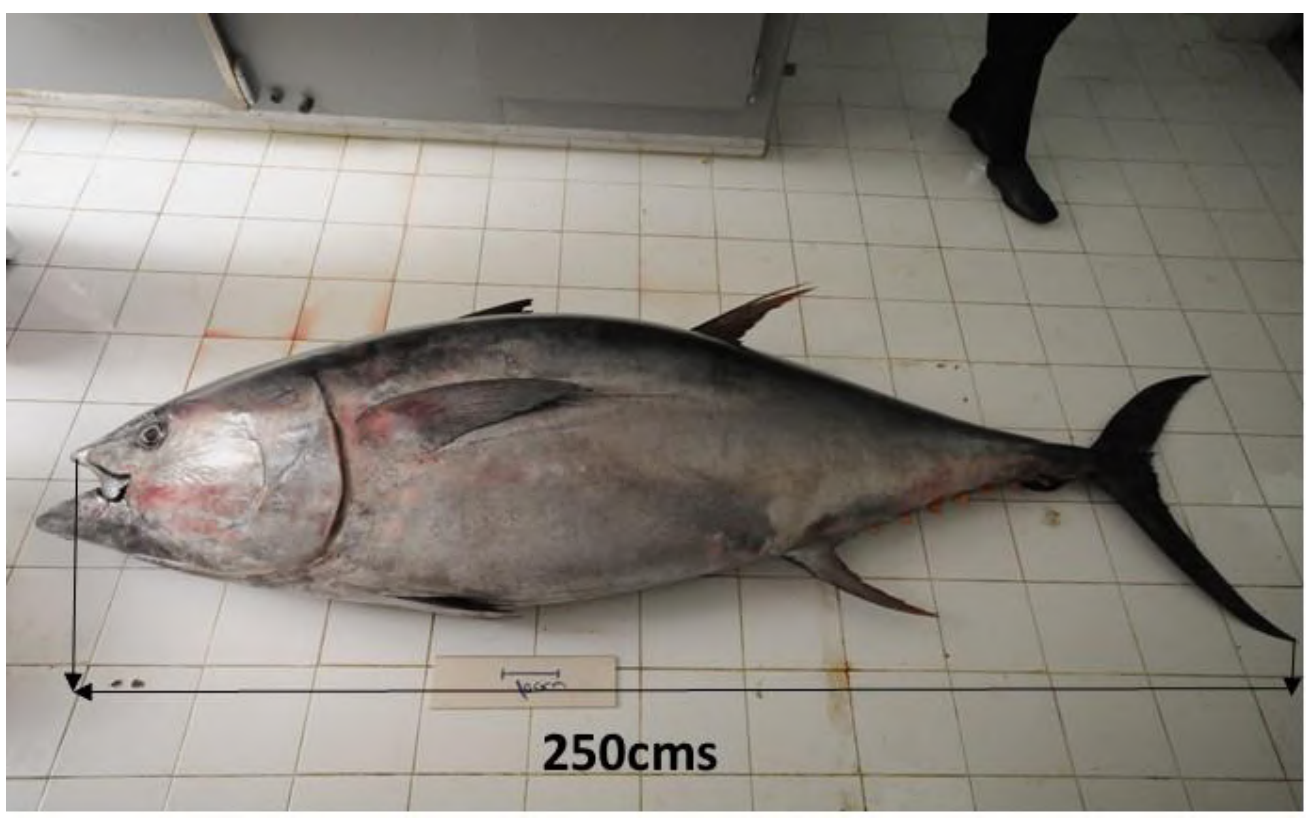

Fig.2: Specimen of T. orientalis collected from Oman 


\section{MATERIAL EXAMINED}

One specimen, Fig. 2, is $250 \mathrm{~cm}$ total length (TL), (204 cm standard length- SL; $224 \mathrm{~cm}$ fork length- FL); caught by long line; 11 May 2017. Atconfluent of Sea of Omanand Arabian Sea coast of Oman. It is difficult to say precisely because the fisherman did not have GPS (global positioning system).

The sample was brought to the Marine science laboratory at the Marine Science and Fisheries Centre, Ministry of Agriculture and Fisheries Wealth, Sultanate of Oman for analysis. After weighing,the morphometric and meristic characters of the fish were recorded following standard procedures (John\& Schaefer, 1949). Then, the fish was cut open to identify the sex, maturity stage of the gonad and feeding intensity. The liver and air bladder structure were observed. Otoliths were extracted from head for subsequent age analysis. The muscle tissue was collected for genetic analysis. The fish sample was buried to preserve and display the bones in the museum.

\section{Description}

The fish weighed $237 \mathrm{~kg}$ and was a mature male. The feeding intensity was $1 / 2$ full stomach and the food was in fully digested state. Ventral surface of liver was striated with blood vessels. Air bladder was irregular. There were 36 gill rakers in the first left gill arch (Fig. 3)

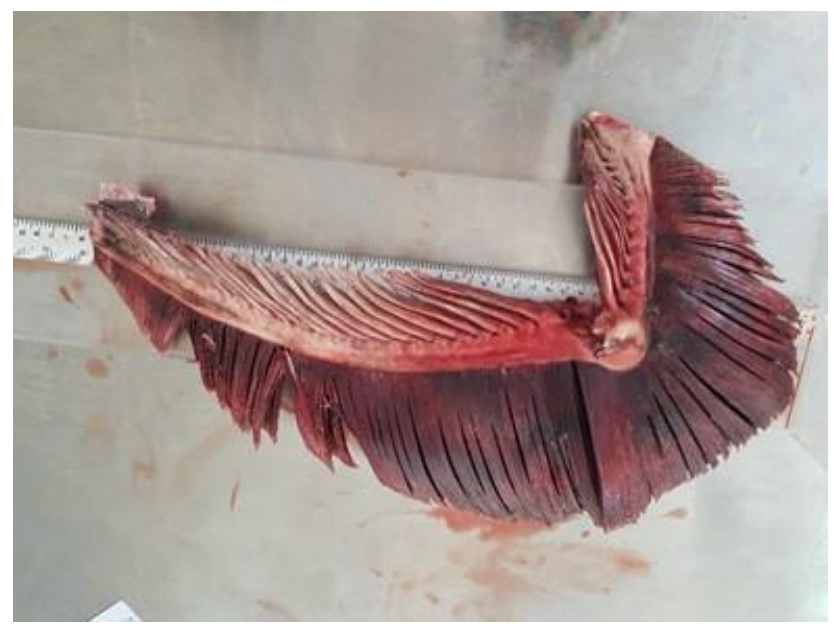

Fig.3: First gill arch- Total gill rakers- 36.

The morphometric characters (Table- 1) and meristic counts (Table- 2) of the specimen agree with the descriptions of the species $T$. orientalis which was further confirmed by the genetic analysis of mitochondrial DNA with D-Loop (NCBI. Accession No. JN631213.1).

Body: Fusiform, almost round, very robust in front and tapering towards caudal peduncle. Head lengthless than body depth. Mouth large,teeth small and conical in a single series. The first dorsal height less (10.7\% of FL) than the second dorsal fin height ( $16.1 \%$ of FL) in the present specimen; pectoral fin short and less than head length and about $17 \%$ of FL. In T. orientalis, the short pectoral fin and heights of 1 st and $2^{\text {nd }}$ dorsal fins are considered as the prominent morphometric characters to identify the species (Nelson, 2006).

Coloration: Lower side of belly was silvery white but no other colour pattern was visible. This might be due to the delay in bringing the specimen to the laboratory after three days. However, in fresh specimens lower sides and belly are with faint colourless transverse lines alternated with rows of faint colourless dots (Collette et al., 1983; Nelson, 2006; Tamura \& Takagi, 2009).The first and second dorsal fins were dark bluish with dusky yellow tips. Dorsal and anal Finlets were yellowish, base reddish-brown towards middle and tips. Median caudal keel was black.

Table.1: Important morphometric measurements of T. orientalis

\begin{tabular}{|l|l|r|r|}
\hline S.No. & \multicolumn{1}{|c|}{ Morphometric measurements } & $\mathrm{cm}$ & In FL (\%) \\
\hline 1 & Head length & 57 & 25.4 \\
\hline 2 & Head depth & 51 & 22.8 \\
\hline 3 & Pre-opercle length & 44 & 19.6 \\
\hline
\end{tabular}




\begin{tabular}{|c|c|c|c|}
\hline 4 & Post orbital distance & 33 & 14.7 \\
\hline 5 & Eye Diameter & 6 & 2.7 \\
\hline 6 & Upper jaw length & 20 & 8.9 \\
\hline 7 & Body depth & 131 & 58.5 \\
\hline 8 & Girth & 59 & 26.3 \\
\hline 9 & Distance snout to eye & 19 & 8.5 \\
\hline 10 & Distance snout to nostril & 17 & 7.6 \\
\hline 11 & Distance snout to $1^{\text {st }}$ dorsalfin base & 66.5 & 29.7 \\
\hline 12 & Distance snout to $2^{\text {nd }}$ dorsalfin base & 116 & 51.8 \\
\hline 13 & Distance between $1^{\text {st }}$ and $2^{\text {nd }}$ dorsalfin & 22 & 9.8 \\
\hline 14 & $1^{\text {st }}$ Dorsalfin length & 49 & 21.9 \\
\hline 15 & $1^{\text {st }}$ Dorsalfin height & 24 & 10.7 \\
\hline 16 & $2^{\text {nd }}$ Dorsalfin length & 20 & 8.9 \\
\hline 17 & $2^{\text {nd }}$ Dorsalfin height & 36 & 16.1 \\
\hline 18 & Analfin length & 15 & 6.7 \\
\hline 19 & Analfin height & 36 & 16.1 \\
\hline 20 & Pectoralfin length & 38 & 17.0 \\
\hline 21 & Caudal peduncle length & 8 & 3.6 \\
\hline 22 & Caudalfin spread & 71 & 31.7 \\
\hline 23 & Median keel height & 5 & 2.2 \\
\hline 24 & Median keel length & 25 & 11.2 \\
\hline
\end{tabular}

Table.2: Meristic Counts of T. orientalis

\begin{tabular}{|l|l|l|}
\hline S. No. & \multicolumn{1}{|c|}{ Meristic Counts } & No. \\
\hline 1 & $1^{\text {st }}$ Dorsal fin spines & XIII \\
\hline 2 & $2^{\text {nd }}$ Dorsal fin rays & 15 \\
\hline 3 & Dorsal Finlets & 9 \\
\hline 4 & Pectoral fin rays & 30 \\
\hline 5 & Anal fin rays? & 12 \\
\hline 6 & Anal Finlets & 8 \\
\hline 7 & Gill rakers & 36 \\
\hline 8 & Keels & 3 \\
\hline
\end{tabular}

\section{DISCUSSION}

Thunnus orientalis is an epipelagic oceanic species that forms school by size and performs wide horizontal and vertical migrations and seasonally moves close to the shore (Magnuson, 1973; 1978; Kitagawa et al. 2007). This species is distributed in depth range of 1 to $550 \mathrm{~m}$ (Froese \& Pauly, 2009; IUCN, 2014). The fish has great tolerance of sea-surface temperature ranging from $17^{\circ} \mathrm{C}$ to $23^{\circ} \mathrm{C}$ and be able to dive deep waters as cold as $\sim 3^{\circ} \mathrm{C}$ (fish Base). It is a voracious predator feedingprimarily on a variety of small schooling fishes such as anchovies, sardines, herrings, menhaden and mackerels and also on squids, crabs and other less sessile organisms (Collette and Nauen, 1983; Allain, 2005; Swada et al., 2005).
The record of $T$. orientalisfrom the Arabian Sea coast of Oman is significant as the species has been found distributed in north and south Pacific (Ashida et al. 2015; Collette et al. 2014, Lewis, 2012; Itoh et al. 2003; Tanaka et al.2006). Although, this species moves in schools, only single specimen was caught presently. This would lead to speculations such asincidental occurrence owing to disorientation or be linked to the ecological changes that occurred due to rise in water temperature in its distributional ranges causing a decline in prey organisms and hence, migrated to more abundant prey related regions or to unknown biotic and/or anthropogenic factors (Sharp \& Dizon, 1978; Kimura et al., 2010).

The species $T$. orientalis is represented by a single Pacificwide stock that is found primarily in the North Pacific 
Ocean (Kitigawa et al., 2007). Hence, it may be presumed that the migration of the species from the north Pacific to the Arabian Sea coast of Oman might have occurred through the Bay of Bengal. Hence, it would be interesting to know whether the extension of the species distribution is very recent to the countries bordering the Bay of Bengal coast or already established populations are available in the region. Intensive research in this line is needed to better explain the occurrence of a solitary Pacific blue fin tuna from Oman.Tagging studies wouldreveal the possible routes of movement pattern of $T$. orientalis if any, from north Pacific to the western Indian Ocean.

\section{ACKNOWLEDGEMENT}

I would like to thank the fisherman for taking the effort to report to Ministry of Agriculture and Fisheries. Thanks are due to the Director General of Fisheries Research and Director of Marine Science and Fisheries Centre for arranging to purchase the fish sample. Thanks to all staff of the centre for their effort in handling such huge fish specimen.

\section{REFERENCES}

[1] Al-Abdessalaam T.Z.S., 1995. Marine species of the Sultanate of Oman.Ministry of Agriculture and Fisheries, Sultanate of Oman. Publication No. 46/95, 412 pp.

[2] Al-Jufaili, S.M., Hermosa G., Al-Shuaily S.S. and AlMujaini A., 2010. Oman fish biodiversity. Journal of King Abdulaziz University: Marine Science 21 (1): 351.

[3] Allain, V., 2005. Diet of four tuna species of The Western and Central Pacific Ocean. SPC Fisheries Newsletter114: 30-33.

[4] Ashida H, Suzuki N, Tanabe T, Suzuki N, Aonuma E., 2015. Reproductive condition, batch fecundity, and spawning fraction of large Pacific bluefin tuna Thunnus orientalis landed at Ishigaki Island, Okinawa, Japan. Environ Biol Fish., 98:1173-83.

[5] Asiapacifish-

http://www.asiapacfish.org/index.php/species/item/27pacific-bluefin-tuna\#biology.

[6] Boulenger G.A. (1887) An account of the fishes obtained by Surgeon-Major A.S.G. Jayakar at Muscat, east coast of Arabia. Proceedings of the Zoological Society of London 1889, 653-667.

[7] Collette, B.B. and Nauen.C.E. 1983. FAO Species Catalogue Vol.2 Scombrids of the World: An annotated and illustrated catalogue of tunas, mackerels, bonitos, and related species known to date. Retrieved from Rome, Italy.

[8] Collette, B., Reeb, C and Block, B.A., 2001. Systematics of the tunas and mackerels (Scombridae). In: Block, B. A., \& Stevens, E. D. (Eds.). pp. 1-33, Tuna: physiology, ecology, and evolution (Vol. 19). Gulf Professional Publishing.

[9] Collette, B., Fox, W., Juan Jordan, M., Nelson, R., Pollard, D., Suzuki, N. and Teo, S. 2014.Thunnus orientalis. The IUCN Red List of Threatened Species 2014:170341A65166749. http://dx.doi.org/10.2305/IU CN.UK.-

3.RLTS.T170341A65166749.en. Downloaded on 09 July 2017.

[10]Dickson, K.A., 1995. Unique adaptations of the metabolic biochemistry of tunas and billfishes for life in the pelagic environment. Env. Biol. Fish., 42: 65-97.

[11]Fischer, W. and Bianchi, G. (ed.). 1984. FAO species identification sheets for fishery purposes, Western Indian Ocean (Fishing Area 51), Prepared and printed with the support of the Danish International Development Agency (DANIDA), FAO, Rome. Vol. 1: $6 \mathrm{p}$.

[12] Fish cataloguehttp://researcharchive.calacademy.org/research/ichthy ology/catalog/fishcatget.asp?genid=1905.

[13] Fossun et al., 2000. FAO Species Identification Field Guide for Fishery Purposes. Rome. FAO 293pp.

[14] Fouda, M.M., Hermosa Jr. G.V. and Al-Harthi M.S., 1997. Status of fish biodiversity in the Sultanate of Oman. Convention on Biological Diversity, First National Report, Directorate General of Nature Reserves, Ministry of Regional Municipalities and Environment, Sultanate of Oman, pp. 64-104.

[15] Froese, R. and Pauly, D., 2009. FishBase. World Wide Web) electronic publication. http://www.fishbase.org.

[16] Froese R. and Pauly D. (eds), 2011. FishBase. World Wide Web electronic publication, www.fishbase.org. version $(06 / 2011)$.

[17] Godsil, H.C. and Byers.R.D. 1945. A Systematic Study of the Pacific Tunas. The Quarterly Review of Biology, 20(4), 390-390.

[18] Itoh T, Tsuji, S., Nitta, A., 2003. Migration patterns of young Pacific bluefin tuna (Thunnus orientalis) determined with archival tags. Fish Bull. 101:514-34.

[19] Jayabalan N, Shama Zaki and Lubna Al-Kharusi, 2010. First record of the slender ponyfish Equuilites elongatus from the Arabian Sea coast of Oman. Marine Biodiversity Records, Vol. 3, 1-3. 
[20] Jawad L.A. and Al-Mamry, J., 2009. First record of Antennarius coccineus from the Gulf of Oman and second record of Antennarius indicus from the Arabian Sea coast of Oman. Marine Biodiversity Records 2, 1-3.

[21] Jawad, L.A., Juma, M. Al-Mamry, Haithem, K., AlBusaidi, 2014. New record of the keeltail pomfret, Taractes rubescens (Jordan \& Evermann, 1887) (Perciformes: Bramidae) from the Sea of Oman. International Journal of Marine Science, Vol.4, No.25 227-230 (doi: 10.5376/ijms.2014.04.0025).

[22] Kimura, S., Kato, Y., Kitagawa, T. and Yamaoka.N, 2010. Impacts of environmental variability and global warming scenario on Pacific bluefin tuna (Thunnus orientalis) spawning grounds and recruitment habitat. Progress in Oceanography, 86(1-2), 39-44.

[23] Kitagawa, T., Boustany, A.M., Farwell, C.J., Williams, T.D., Castleton, M.R. and Block, B.A. 2007. Horizontal and vertical movements of juvenile bluefin tuna (Thunnus orientalis) in relation to seasons and oceanographic conditions in the eastern Pacific Ocean. Fisheries Oceanography, 16(5), 409-421.

[24] Lewis, A.D., 2012 Conservation Management and Measures (CMM) Report on CMM 2010-04 (Pacific Bluefin Tuna). Western and Central Pacific Fisheries Commission. Northern Committee Eighth Regular Session. 3-6 September 2012. Nagasaki, Japan.

[25] Magnuson, J.J., 1973. Comparative study of adaptations for continuous swimming and hydrostatic equilibrium of scombroid and xiphoid fishes. Fish Bull., 71 (2):337-356.

[26] Magnuson, J.J., 1978. Locomotion by scombrid fishes: hydrodynamics, morphology, and behavior. Fish Physiol., 7: 239-313.

[27] John, C.M. and Schaefer, M.B. 1949.Definitions of body dimensions used in describing tunas. U.S. Fish Wild. Serv. Fish. Bull. 51:241-244.

[28] McKoy J, Bagley N, Gauthier S and Devine J (2009) Fish resources assessment survey of the Arabian Sea coast of Oman, Technical Report 1, Bruce Shallard and Associates, New Zealand, 189 pp.

[29] NCBI- http://www.NCBI.

[30] Nelson, J.S., 2006. Fishes of the world. 4th ed. John Wiley and Sons, Hoboken, New Jersey.

[31] Norman J.R. (1939) Fishes in the John Murray Expedition 1933-34. British Museum (Natural History), London Scientific Reports 7, 1-116.
[32] Randall, J. E., 1995. Coastal Fisheries of Oman, United States of America, University of Hawaii Press. $432 \mathrm{pp}$.

[33] Regan C.T., 1905. On fishes from the Persian Gulf, the Sea of Oman, and Karachi, collected by Mr. F.W. Townsend. Journal of the Bombay Natural History Society 16, 318-333.

[34] Sawada, Y, Okada, T., Miyashita, S, Murata, O. and Kumai, H., 2005. Completion of the Pacific bluefin tuna Thunnus orientalis (Temminck \& Schlegel) life cycle. Aquaculture Research, 36(5), 413-421.

[35] Sharp, G.D. and Dizon, A.D., 1978. The Physiological Ecology of Tunas. Academic Press, New-York: 485 p.

[36] Stromme, T., 1986. Pelagic and Demersal Fish Resources of Oman, Results of the RV Fridjoft Nansen Surveys in Oman 1983-1984, Institute of Marine research, Bergen, Norway.

[37] Steindachner, F., 1902. Fische aus Su"darabien und Soko'tra. Denkschriften der Akademie der Wissenschaften in Wien 71, 123-168.

[38] Tamura, Y. and Takagi.T. 2009. Morphological features and functions of bluefin tuna change with growth. Fisheries Science, 75(3), 567-575.

[39] Tanaka, Y., Satoh, K., Iwahashi, M., Yamada, H.., 2006. Growth-dependent recruitment of Pacific bluefin tuna Thunnus orientalis in the northwestern Pacific Ocean. Mar. Ecol. Press Ser., 319:225-235.

[40] White A.W. and Barwani M.A. (1971) Common sea fishes of the Arabian Gulf and Gulf of Oman. Dubai: Trucial States Council, 170 pp. 